\title{
DIGITAL HUMANITIES PRACTICES AND ARCHIVAL APPRAISAL IN THE CONTEMPORARY ARAB WORLD
}

\author{
Brad Bauer, David Joseph Wrisley
}

Centre d'études et de documentation économiques, juridiques et sociales |

« Égypte/Monde arabe »

2020/2 n²2 | pages 71 à 83

ISSN 2090-7273

ISBN 9782900956229

Article disponible en ligne à l'adresse :

https://www.cairn.info/revue-egypte-monde-arabe-2020-2-page-71.htm

Distribution électronique Cairn.info pour Centre d'études et de documentation économiques, juridiques et sociales.

(C) Centre d'études et de documentation économiques, juridiques et sociales. Tous droits réservés pour tous pays.

La reproduction ou représentation de cet article, notamment par photocopie, n'est autorisée que dans les limites des conditions générales d'utilisation du site ou, le cas échéant, des conditions générales de la licence souscrite par votre établissement. Toute autre reproduction ou représentation, en tout ou partie, sous quelque forme et de quelque manière que ce soit, est interdite sauf accord préalable et écrit de l'éditeur, en dehors des cas prévus par la législation en vigueur en France. Il est précisé que son stockage dans une base de données est également interdit. 


\section{Digital humanities practices and archival appraisal in the contemporary Arab world}

Pratiques des humanités numériques et évaluation des archives dans le monde arabe contemporain

$$
\text { ممارسات العلوم الإنسانية الرقمية والتقييم الأرشيفي في العالم العربي }
$$

\section{Brad Bauer and David Joseph Wrisley}

\section{OpenEdition}

\section{Journals}

Electronic version

URL: http://journals.openedition.org/ema/13166

DOI: $10.4000 /$ ema.13166

ISSN: 2090-7273

\section{Publisher}

CEDEJ - Centre d'études et de documentation économiques juridiques et sociales

\section{Printed version}

Date of publication: 15 December 2020

Number of pages: $71-83$

ISBN: 978-2-900956-22-9

ISSN: 1110-5097

Electronic distribution by Cairn

\section{CAIRN}

CHERCHER, REPÉRER, AVANCER

\section{Electronic reference}

Brad Bauer and David Joseph Wrisley, « Digital humanities practices and archival appraisal in the contemporary Arab world », Égypte/Monde arabe [Online], Troisième série, Digital Archiving in the Arab World, Online since 03 January 2023, connection on 17 December 2020. URL : http:// journals.openedition.org/ema/13166; DOI : https://doi.org/10.4000/ema.13166 


\section{Brad Bauer and David Joseph Wrisley}

\section{DIGITAL HUMANITIES PRACTICES}

AND ARCHIVAL APPRAISAL

IN THE CONTEMPORARY ARAB WORLD

\section{SUMMARY}

Our paper explores ways in which contemporary scholarly practices in the digital humanities $(\mathrm{DH})$ can utilize archival documents as "raw" material for analytical and digital storytelling purposes. We argue, on the one hand, that there is an interpretative potential in uncurated documents that $\mathrm{DH}$ practices can unlock, and on the other hand, that the archival appraisal process needs to be attentive to such scholarly reuse and the data/information value of documents. After a review of the types of collections held by New York University Abu Dhabi, and a review of the history of archival appraisal theory, we present some case studies drawing on Wrisley's undergraduate teaching in $\mathrm{DH}$ using primary documents from and about the Gulf region (a small fold-out simplified map of Abu Dhabi Island, a 1940 German large format map of North-East Africa, a British travel narrative in Arabia from 1933, and Abu Dhabi phone directories from the 1970s). In the end, we argue for the strong collaboration between the archivist and the digital humanist for building and using archival collections. 


\section{INTRODUCTION}

In this paper, we focus on archival documents that inform the multinational, multilingual history of the Arabian Gulf region and their appraisal in view of the present and future use in digital scholarly research. The perspective we adopt is that the appraised document - after acquisition and digitization - can have an immediate reuse value. The capacity for reuse is determined, of course, by both the form of the object, the concerns of digital researchers and the way that it is manipulated for research reuse. Often that transformation takes several steps requiring specialised expertise. Objects that matter [objets qui comptent], Kaplan suggests, are those that hold many meanings-material, historical, even emotional-and these objects compel us to make new uses, and new interpretations, of them (Kaplan 2012: 15).

Of course, this has been the case of archival practices, long before the age of the computer and the internet. With digital environments, however, we argue that we develop a special eye for the acquisition and appraisal of potential archives for digital reuse and there is a need for contemporary libraries and archives to be more aware of workflows that lead us from collections to scholarship.

Our paper is divided into three main sections: a look at "new" collections in the Gulf, a discussion of archival appraisal theory and its applicability to these environments and a brief discussion of four documents already located in New York University Abu Dhabi (henceforth, NYUAD) Archives and Special Collections (ASC). We discuss ways that researchers have studied and reused these documents in digital environments. Understanding these potential use values is one way, we argue, that the digital humanist and archivist can collaborate toward building archival collections.

\section{BACKGROUND OF "NEW" COLLECTIONS OF THE INSTITUTIONS OF THE GULF, AND INSTITUTIONS LIKE NYUAD}

Upon the opening of the new library on NYUAD's Saadiyat Island campus in 2014, the ASC Department of the library was established to collect, safeguard, and provide access to rare and unique materials acquired by the library in support of the teaching and research needs of the university's faculty and students. In addition, the ASC was envisioned as building substantial collections that would contribute to the cultural patrimony of the United Arab Emirates, and as such, would be open and accessible to users from the broader community who had no affiliation with the university. Several distinct collecting areas were identified at the outset, and were created in response to existing and anticipated research needs within the university, as well as areas of interest relevant to the broader community in Abu Dhabi and the UAE. 
These areas included an emphasis on collecting historic maps of the region, which encompass the Gulf, the Arabian Peninsula, and the Indian Ocean region; a collection of films from Arab and regional filmmakers, many of which screened at the Abu Dhabi Film Festival between 2010 and 2014; and an area of collecting referred to as "Arab Heritage," which consists of general works about or related to the social and cultural history of Abu Dhabi, the United Arab Emirates, and its surrounding region. This latter category includes materials in a variety of formats and media, ranging from rare books, magazines, pamphlets, and ephemera, to collections of personal papers and archives. Given that the nations bordering the Arabian Gulf and the Indian Ocean have cultural and commercial ties that stretch back over several centuries, the collections at NYUAD seek to reflect that and to provide materials that will be useful to scholars and students from a wide array of disciplines and areas of research interest.

In the past five years of its existence, in addition to the over 1,500 books, maps, and other publications acquired by the department, the Library has also acquired several dozen archival collections, including:

- Ali Akbar Bushiri collection: a collection of correspondence, business ledgers, photographs, and documents that depict the experiences and activities of an extended family of Iranian merchants in Manama, Bahrain during the early to mid 20th century.

- Marcel Kurpershoek collection: the papers, notes, books, and recordings of a Dutch diplomat and scholar of oral poetry traditions of the Bedouins of central Saudi Arabia, including his field recordings and transcriptions of such poetry.

- Salwa Mikdadi collection: an extensive archive from an NYUAD art historian specializing in modern art of the Middle East and the Arab diaspora, containing dossiers on the work of several hundred modern Arab artists, and documents relating to exhibitions of modern Arab art that she has curated in the United States and the UAE.

- Frauke Heard Bey and David Heard collection: a collection of several hundred publications, ranging from limited circulation newsletters, government publications, periodicals, and other materials related to the history of Abu Dhabi and the United Arab Emirates during the past half-century, and focusing on topics such as the oil industry, women's education, and the economic development of the emirate.

- Graham A. Hill papers: a small collection of photographs and documents from a British army officer who served with the Trucial Oman Scouts, and later the Union Defence Forces, in Sharjah from 1970-1974.

- Emirates Bird Records Committee collection: the records of a group of expatriates who have meticulously documented the appearance of a variety of bird species across the UAE through recordings of bird sightings across the country from the 1970s onward. 
These collections represent a sample of the types of topics covered by the archives, and the library's collection of rare books also includes material as varied as accounts of European travellers in the region from the 18th and 19th centuries, a Turkish atlas that encompasses the region published in the early 1700s, early European published versions of key medical texts from the Arab world, including works of Ibn Sina, and albums of photography from early 20th century visitors to the Gulf. All of these works underscore the theme of the Gulf region as a cultural and commercial crossroads dating back several centuries.

There is a key difference between these older publications and much of the documentation mentioned in the above six collections: their age. One of the complex aspects of digital scholarship that utilizes special collections from modern societies of the Gulf region stems from the potential use of documents that are not yet in the public domain, due to copyright protections or other restrictions on the reproduction or dissemination of the documents. The particular approach that we take in this paper is not that we need to digitize such documents for the purposes of access (a perfectly acceptable goal in itself), but rather digitizing such documents for the purpose of extracting different kinds of data from them. The term "derivative data» in the context of information studies denotes data that has been drawn from a document collection, without being the documents themselves. Another way of thinking about the idea of derivative data is that such data do not give a user enough information to reconstruct the original documents. Derivative data from archival sources are generally held to be original acts of interpretation, and especially when a scholar recombines them for the purposes of dissemination and interpretation about those materials.

\section{ARCHIVE APPRAISAL THEORY}

In seeking to address how traditional archival appraisal criteria may be impacted by the advent and continued growth of digital humanities research, it might be helpful to take a brief look at the history of archival appraisal theory over the past century. Since NYU Abu Dhabi is an institution that while truly global, has North American roots, many of the practices in archival management have been defined by traditions originating from there, and from archival practices of the larger Anglophone world.

In the first half of the 20th century, most archival appraisal practice was shaped by the work of the influential British archival theorist Hilary Jenkinson, of the Public Records Office (U.K.), and his American counterpart, Theodore (T.R.) Schellenberg, of the U.S. National Archives. Jenkinsonian appraisal theory focused on the role of the archivist as a custodian of records. In order to ensure a high degree of impartiality in the shaping of the historical record, this school of appraisal theory stressed that only record creators could suitably address which records should be placed in the archives and which should not. The role of the archivist was to safeguard, describe, and preserve records, but 
less so to determine which ones were truly "archival" and representative of an individual's or organization's activities. In this way, the integrity of records would be maintained, and kept free from the biases of individual archivists (Ham 1993: 9). Schellenberg, by contrast, envisioned a much more active role for the archivist, who was empowered to analyze and select documents according to their evidential and informational value. This required knowledge on the part of the archivist of an organization's structure and activities, and the ability to assess which records had value on the basis of what they revealed about the motives, actions, and activities of records creators. Their value was found as well as in the other types of information contained in these records that might have value to later users and researchers, aside from the original purposes of these documents (Ham 1993: 7-8; Boles 2005: 11-13).

It should be noted though that both Jenkinson and Schellenberg, as well as many of the archivists who responded to their writings, worked in governmental or institutional archives, and handled the records of organizations, rather than the private papers of individuals. Only much later, in the late 1960s and early 1970s, with the growing emphasis among historians toward writing a social history that focused on the histories of societies at the grass roots, shifting away from a focus on elites, did the archival profession begin to look outward, and begin to seriously grapple with how to ensure that the voices of those parts of society outside of leaders of corporations or governmental agencies, were adequately represented in the archives. The desire to create a "representative record of human experience" in the words of F. Gerald Ham led to a broader movement to look at individual archival collections - both those that already existed in repositories and potential new acquisitions within a larger context, across archival repositories (Boles 2005: 18-21). Some advocated that archivists look more broadly at society and work together to identify individuals, communities, or social movements whose records were missing from the archives, and to work together to address such gaps in the record through documentation strategies that mapped out potential areas of acquisition. Others sought to analyze the functions carried out by organizations such as universities, government agencies, or corporations, and through such functional analysis identify the types of records that would be created as evidence of these functions, and to make the acquisition of such records the primary focus of archival appraisal (ibid.: 21-22, 28-30).

In summarizing the history of archival appraisal over the past century, the American archivist and educator Frank Boles noted two poles underlying many of these approaches: that archivists who work for institutional archives tend to be focused largely on preserving evidence of the activities of their parent organization, and that archivists working in what have been called "collecting repositories", such as those in universities, historical societies, and libraries, place a much higher priority on selecting archives that meet the informational needs of their users (ibid.: 35-36). Rather than choosing one approach over the other, Boles argues that archivists must above all be 
pragmatic, and that "the purpose of archives is whatever a particular society or institution wishes rather than the mandate of a universal principle». Furthermore, both the context of a record's creation and the content of such records are important; it is the "objective of the archive determines that balance between the two" (ibid.: 40-41).

Within this context, the archives of NYU Abu Dhabi have been more heavily weighted toward the latter priority, seeking to acquire collections with an eye toward their anticipated use by students and scholars, as well as looking for niches within the archival landscape of the UAE and the Gulf region, which the NYUAD archivists can help fill through their collecting activities. Yet, in addressing the changing needs of its users, and the archival and other information resources available in the $U A E$, the staff of the archives and special collections at the NYUAD Library are forced to ask a number of questions in response to Boles' call for greater pragmatism in archival appraisal and selection. One such area that is forcing this change is the growing interest in the digital humanities $(\mathrm{DH})$, both throughout institutions of higher education around the world, but more specifically, among NYUAD's faculty and students.

Traditionally archivists appraise collections based on their aggregate content, as groups of documents that are informationally rich, and have the potential to address a variety of research questions and interests. Less attention is given to the analysis of individual documents within such collections, let alone to identifying potential areas of research that could emerge from them. Some archivists would be wary of trying actively to identify such specific research projects, echoing Jenkinson's call toward impartiality, and not wanting users to be forced to view such collections through the filters imposed by the personal research interests or biases of the archivist. $\mathrm{DH}$ practices in research and in the classroom at a university like NYUAD, however, have led to a greater awareness of the value of individual documents or groups of documents for digital projects, and have had the effect of leading archivists and special collections librarians to take a closer look at such individual items within collections, and to experiment with learning the methods of reuse of such items. Several of the projects that follow in the rest of the paper illustrate novel ways in which individual items, maps, books, or documents have been utilized for DH teaching and research at NYUAD, and as a result, have begun to shape the appraisal criteria within Archives and Special Collections as well.

\section{FOUR CASE STUDIES IN DIGITAL SCHOLARSHIP USING NYUAD ARCHIVES AND SPECIAL COLLECTIONS}

Contemporary digital scholarly practices utilize archival documents as "raw" material for meaning-making purposes. In the remainder of this paper, we present some research case studies, sometimes embedded in the activities of the undergraduate classroom, using four documents from and about the Gulf 
region (1) a commercial flyer for an Abu Dhabi bank from the late 1960s, (2) an inset from a large format map of Northeast Africa from the 1940s (3) a 1933 Orientalist classic travel narrative and (4) local phone directories from the United Arab Emirates from the 1970s. The four objects have all been utilized for scholarship using digital methods such as geo-rectification, vectorization, digital exhibit building and information extraction.

Let us be clear, however. All of these objects already existed in our ASC; none of them was a candidate for acquisition. Each one of them poses, however, interesting questions to the notion of archival appraisal on account of its form, its informational value and its relationship to the archive's collection strategies. In order for the reuse potential of any given archival object to be unlocked in a world of digital methods, it must first be digitized. Often libraries and archives do not think beyond the process of digitization, seeing that as an end in itself, and not considering how their collections will be used as data (Padilla et al 2019: 11-13). There is a case to be made that archivists and digital researchers should think together, not only about how to make collections accessible for computational research, but also how to better address questions related to digital scholarship earlier in the archival appraisal process. This approach is all the more important in environments such as NYU Abu Dhabi, where archival acquisitions are increasingly utilized for digital humanities projects.

\section{A Small fold-out simplified map of Abu Dhabi Island}

Sometimes objects come to our attention in circumstances that we expect the least. Appraisal, in this case, might not mean whether to acquire an object, but instead whether to keep it when it shows up. The first object we discuss is a small, fold-out commercial map of Abu Dhabi's main island, with a simplified topographic structure and street grid, that according a post on the NYU Abu Dhabi Special Collections Tumblr account, was found tucked into another book acquired by the library (NYUAD Special Collections Tumblr 2016).

The map, shown in figure 1, sets Abu Dhabi island against a blue background, and only in the inset detail at bottom left shows how the city is connected to the mainland, via the famous Maqta Bridge constructed in 1967. The exact date of the map is unknown, but certainly post-dates the bridge's construction. If we supplement our analysis of this document with contemporary aerial photography of the city, we can see that the area on the map with the landmarks indicated by numbers corresponds roughly to the size of Abu Dhabi in the same period. ${ }^{1}$

1 For example, there are albums in image hosting services like Flickr made by former expatriate residents of Abu Dhabi who documented the city in the 1960s. URL: https:// www.flickr.com/photos/dsriley1/8480602571/in/album-72157649702828158/

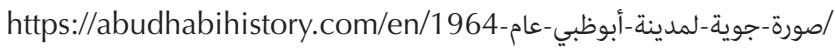



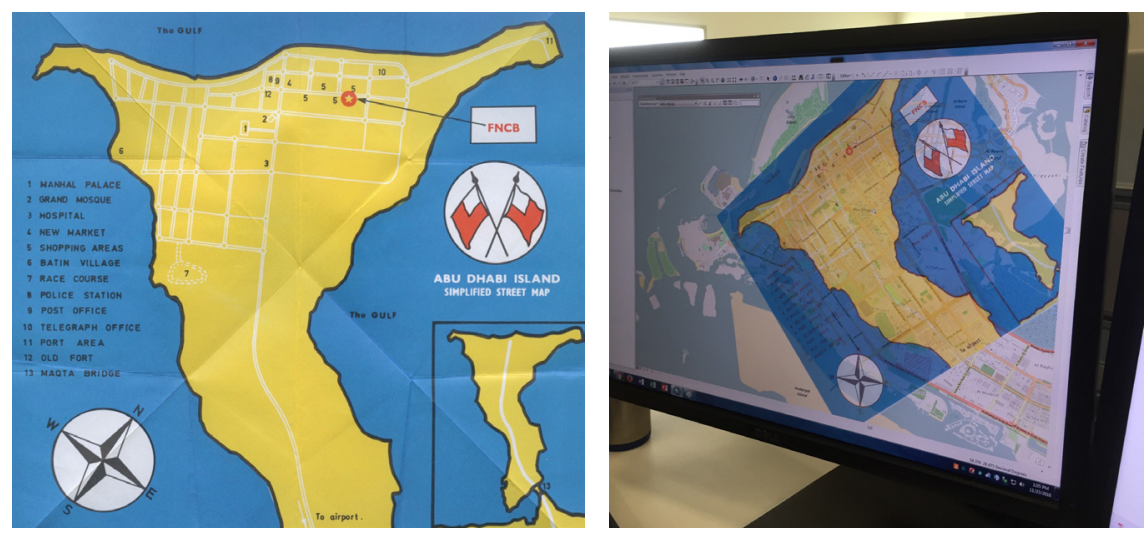

Figure 1. A small fold-out commercial map of Abu Dhabi island, distributed by First National Commercial Bank (FNCB) in Abu Dhabi (at left) with a digitized image of the same map, georeferenced and overlaid onto an OpenStreetMap base map of the city in ArcGIS. Source: ASC, NYUAD Library

We subjected the map to spatial analysis in a Geographic Information System (GIS), whereby we attempted to take a digitized version and fit it to a modern geographic grid, through a process known as geo-rectification. Even though this process shows that its scale and orientation are only approximate, this map is precisely the kind of documentation that allows us to reconstruct the urban layout around the time of British withdrawal from the Trucial States in the early days of the UAE's capital city. Despite the fact that we often think about a GIS as a strictly quantitative environment, spatial analysis in the humanities, is in reality, "generally qualitative, visual and intuitive" (Travis 2015: 19). For the digital researcher interested in spatial representations, such a fold-out, bank-issued map contains a hoard of useful, qualitative information.

\section{Extracting data from an inset on large-format map of North-East Africa}

As mentioned above, one of the emphases in the ASC's collection strategy has been on collecting historic maps of the region, encompassing the Gulf, the Arabian Peninsula, and the Indian Ocean region. The second document we discuss is a recently acquired World War II era German map of "Nordost-Afrika" (North-East Africa). This map has several distinguishing features that make it a strong candidate for acquisition by a university archive. Space does not allow us to elaborate on them here, but we will focus on one small detail. In the inset at the bottom of the larger map (figure 2, left) is found the rough depiction of the borders of "Possessions, Protectorates and Mandates" in the year 1940.

Of particular interest in this inset map to a researcher are the borders of Saudi Arabia in 1940, notably the border with the Sultanate of Muscat and Oman that is significantly different from the boundaries of these two nations 

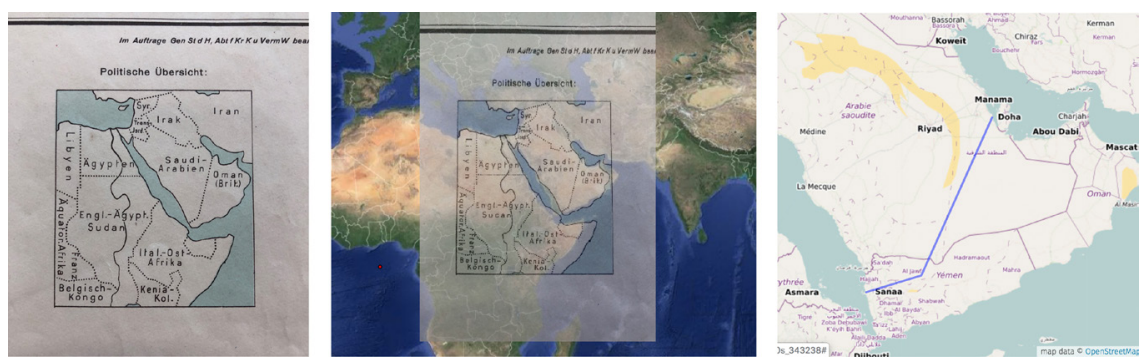

Figure 2. A small inset "Politische Übersicht" (Overview of Political Borders) found at the bottom left corner of a larger German map of "Besitzungen, Protektorate und Mandaten» (Possessions, Protectorates and Mandates) in the Middle East and North East Africa, published in 1940. A georectified version of the same map (right) sits on top of a satellite view of the same space. Finally, we have vectorized the Omani protectorate border and placed it on top of today's political borders on an Open Street Map raster (right). Source: Nordost-Afrika, 1:5,000,000 [map], G8222.A3 N67 1940, ASC, NYUAD Library. Base map (far right): OpenStreetMaps

that we know of today. We imported the map into a GIS, in a way analogous to Document 1; however, unlike the bank map, Document 2 is clearly a professionally made map. Since the Saudi Arabian - Omani border was of interest to us, we can resort to a procedure known as "vectorizing" that allows us to trace over any feature on the georeferenced map. That way we can extract just that single feature and reuse it within the context of another map in a GIS. The blue line in the third image (far right) of figure 2 demonstrates what the 1940 border looks like overlaid on contemporary political borders. This procedure is essential in as much as we can move one feature of an archival map and then visualize it in other contexts such as an interactive map of today's Arabian Peninsula for illustrative purposes. ${ }^{2}$

\section{The 1933 edition of St John Philby's The Empty Quarter}

Harry St John Philby's book The Empty Quarter is a classic of Orientalist writing that in its 1933 edition is published with a large fold-out Royal Geographic Society map of his travels pasted inside its covers. The book and the map are not in the public domain, so we could not digitize it and publish it for access via the web. Faced with this dilemma, one of Wrisley's undergraduate courses set out to make a digital exhibit using the book as an inspiration rather than a digitized document. The exhibit is entitled "Discovering the Empty Quarter"

2 The 1940s border as represented by the German map can be seen here: URL: http://umap.openstreetmap.fr/en/map/british-oman-rough-border-1940s_343238\# 5/25.919/48.889, consulted on 07/12/2020. 
and can be consulted online. ${ }^{3}$ We used the web-publishing platform known as Omeka Classic for building and describing a collection of digital images. ${ }^{4}$

We were able to obtain a full-text searchable version of The Empty Quarter, allowing us to search for recurrent patterns, but in building the digital exhibit, we encountered an "image problem." Whereas digital exhibits are largely driven by a combination of text and image, the region of the Empty Quarter is not well-documented photographically. Furthermore, of the images we were able to identify in digital collections, few were published with open licenses for reuse. The challenge of creating digital scholarship from such a document was in collecting related content that was appropriately illustrative. Had we had an Arabian Peninsula photography collection in ASC, our project would have been easier.

The exhibit ended up focusing on his distinct naturalist orientation in The Empty Quarter and how that style also gives us access to his political and geographic mindsets. Our solution lay in a combination of textual analysis of the book and searching for images in free repositories (such as Wikimedia or Flickr's Creative Commons-licensed repositories) that corresponded to the general landscapes described therein. One of the students in the course even sketched out landscapes based on Philby's detailed descriptions of landscape, flora/fauna of Arabia, and on his repetition of the theme of water. In retrospect, the lesson of working with this document was that its contents - naturalist, geographical, travel-related - are perfect topics around which many other collections, such as the new Emirates Bird Records Committee collection could be combined. It encourages us to think about making some of the existing collections available for digital reuse and, when available, to acquire complementary materials with such reuse in mind.

\section{Emirati phone directories from the 1980 s}

In many research fields that have made a digital turn, researchers suffer from an acute sense of information overload. At first, it may not seem that this is the case in the archives of Gulf cities such as Abu Dhabi. On the other hand, if we imagine the history of Abu Dhabi from an increasingly expanding set of non-traditional documents, and we bring computational methods to that expanding set, we quickly arrive at a challenging situation. We could undoubtedly begin to include oral histories and multilingual documentation of its many expatriate communities, as we could also include potential genres of sources that have not yet been exploited for derived data that we can created from them: flyers, menus, newspaper advertisements, insurance maps, social club registers, even public phone books.

3 http://djwrisley.hosting.nyu.edu/Philby/exhibits/show/eq/introduction.

4 https://omeka.org/classic/. 

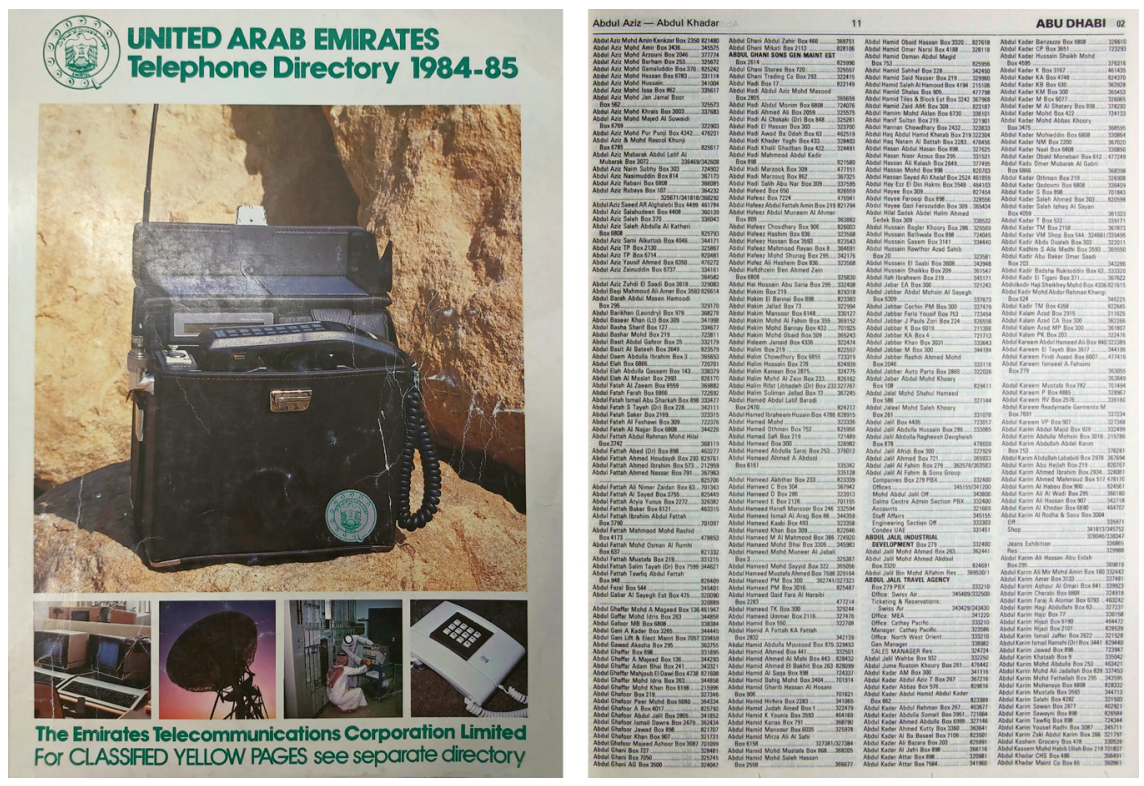

Figure 3. The cover of a telephone directory from 1984-1985 (at left), published by the Emirates Telecommunications Corporation Limited. A sample page (at right) from the portion of the directory listing numbers in Abu Dhabi. Source: Frauke Heard-Bey and David Heard Collection, MC.064, ASC, NYUAD Library.

Cinema scholars have begun to turn to such documentation. The same can be said of art history (Artl@s 2019). The adoption of an expanded base of research evidence takes them far beyond the film or pieces of visual art, to reconstruct larger contexts for understanding their history. It has been argued that such documents "expand the amount of information available to us and lift the significance of our ability to locate, collect, aggregate, curate, manipulate and analyse different data formats from different sources and for which available tools are proving increasingly inadequate" (Verhoeven 2012: n.p.). The dual challenge of seeing history in broader frameworks and expanding our methodological toolkit takes us back to the main argument of our paper: build open lines of communication between archivists and digital researchers about that changing information landscape.

Figure 3 shows the cover of a Telephone Directory from 1984-1985 (at left), open to a sample page from the portion of the directory with numbers in Abu Dhabi (at right). On this page, we read personal and commercial names, post office box addresses and phone numbers, at a moment when phone numbers were 6 digits long. ${ }^{5}$ Drawing on the roughly geographical quality of telephone

5 Wireline/geographic subscriber numbers expanded in Abu Dhabi from 6 to 7 digits around 2000. 
exchanges and the initial digits of a phone number to mark a particular area of town, it would not be too difficult to sort the numbers in such a directory with the help of a computer. Even if we do not have street addresses listed in this document, it could give us a good idea of what kinds of businesses, institutions or even family names cluster in which general parts of the city in the 1980s. This could point to shifting patterns in the organization of the city or its commercial networks, or even to markers of national belonging and religious identification in the capital in its early days (Mirza, Wrisley 2020).

Public phone books, such as the one pictured above, are abundant, but one could easily imagine them disposed of, or overlooked, in special collections. Digital history is increasingly adopting creative methods to use such directories for new purposes, such as discovering patterns of land use, identifying migrant communities or documenting commercial activity (Bozdogan 2016: 14). It is certainly a perspective that could encourage new ways of thinking about situated, urban histories in the region growing from the kind of acquisitions that NYU Abu Dhabi has made in recent years.

\section{CONCLUSIONS}

Digital humanities $(\mathrm{DH})$ research has a long track record of working with archives - and with archivists - as part of the process of curation and interpretation of the human past. This article has focused on printed materials relevant to the Gulf region: old editions, maps and government-issued directories. As we described above, the NYU Abu Dhabi archives have focused in their almost ten years of existence on many modes of documentation related to culture and society: human creative expression in film, sound, visual art, as well as documentary materials about climate and natural environments. Access to a media-rich archive is a salient topic in libraries nowadays; digital access to archives requires us to rise to new levels of competence when dealing with multimodal contexts. The digital methods required to digitize, preserve and analyze such data are well documented, but every jump in genre or medium renders the expertise to handle them - as well as to integrate them into daily scholarly practice - significantly more complicated. Our central claim in this article - that the archival appraisal process needs to be aware of contemporary digital scholarly practices - is perhaps one way that our new archival environments can grow with an eye toward their anticipated use by scholars, as well as looking for filling out gaps in the archives for the UAE and the Gulf region that have not received as much attention as they deserve. 


\section{BIBLIOGRAPHY}

Artl@s Project, https://artlas.huma-num.fr/en/, consulted on 01/07/2020.

Balachandran A., Pinto R., 2008, Archives and access, Bangalore: Center for Internet and Society.

Boles F., 2005, Selecting and appraising archives and manuscripts, Chicago: Society of American Archivists.

Bozdogan S., 2016, "EAHN Conference, Dublin June 2-5, 2016: Closing remarks", Architectural histories, vol. 4, no. 1, p. 14, URL: https://journal.eahn.org/articles/10.5334/ ah.236/, consulted on 01/07/2020.

Duranti L., 1994, "The Concept of appraisal and archival theory", American Archivist, vol. 57, p. 341-344, URL: https://doi.org/10.17723/aarc.57.2.pu548273j5j1p816.

Ham F. G., 1993, Selecting and appraising archives and manuscripts, Chicago: Society of American Archivists.

Hughes L. (ed.) 2012, Evaluating and measuring the value, use, and impact of digital collections, London: Facet Publishing.

Kaplan F. 2009, La Métamorphose des objets, Limoges: Éditions Fyp.

Mirza M.W., Wrisley D.J., "Abu Dhabi Calling!: A Pilot Investigation of Spatial Patterns in Phone Directories" in NYU Libraries Faculty Digital Archive, published on 20/01/2020, URL: http://hdl.handle.net/2451/61212, consulted on 01/07/2020.

NYUAD Special Collections, "A Bank-issued map unexpectedly found tucked inside", in Tumblr, published in 2016, URL: https://nyuadspeccoll.tumblr.com/post/142284575956/ a-bank-issued-map-unexpectedly-found-tucked-inside, consulted on 01/07/2020.

OpenGulf, URL: http://opengulf.github.io, consulted on 01/07/2020.

Padilla T. et al., "Final Report - Always already computational: Collections as data", in Zenodo, published on 22/05/2019, URL: https://zenodo.org/record/3152935, consulted on 01/07/2020.

Riley D., "Album: Abu Dhabi 1962/64", in Flickr, n.d., URL: https://www.flickr.com/photos/ dsriley1/albums/72157649702828158/with/15998086619/, consulted on 01/07/2020.

Sumner M., Wrisley D.J., "NYUAD GIS day: exploring Cold War-era maps of the UAE", NYU Libraries Data Services (blog), published on 23/11/2016, URL: https://data-services.hosting.nyu.edu/nyuad-gis-day-2016/, consulted on 01/07/2020.

Travis C., 2015, Abstract machine: Humanities GIS, Redlands (CA): ESRI Press.

Verhoeven D., 2012, "New cinema history and the computational turn," in WCCA 2012: Beyond art, beyond humanities, beyond technology: a new creativity, World Congress of Communication and the Arts conference proceedings. Guimarães (PT), COPEC Science and Education Research Council, n.p. 
